\title{
1 Evolution and Diversity of the Flora
}

Land plants arose almost 500 million years ago (Ma). Those with a vascular system (lycopods) appeared at least $450 \mathrm{Ma}$, followed by the ferns with true leaves rather than scales at least $400 \mathrm{Ma}$. Seed-bearing plants originated about $430 \mathrm{Ma}$ giving rise to the gymnosperms about $330 \mathrm{Ma}$, including the cone-bearing cycads in one clade (phylogenetic group) and the conifers in another.

The latest research based on rates of change in DNA structure (the molecular clock) puts flowering plants arising at least $134 \mathrm{Ma}$ but it may have been up to $248 \mathrm{Ma}$ depending on the true affinity of different fossils and the accepted rates of molecular change and whether a group is only recognised once it starts to separate into its daughter groups (called the crown) or at its base where it remains undivided or only a single-ancestor can still be identified at the molecular level (Clark et al., 2011). This puts angiosperm origins in the Permian Period, or as early as the Ordivician, much earlier than once thought. Nevertheless, once the angiosperms appeared they gradually outcompeted all previously existing groups of plants, certainly by the end of the Cretaceous, 65.5 Ma. This was apparently due to their rapid growth rates and superior colonizing ability. Speciation of the SouthWest angiosperm flora was particularly rapid during the Miocene to Pleistocene, a time of great climatic upheavals with a general drying and cooling trend from 15 Ma (Fig. 1.1), including a period of severe aridification 2-5 Ma (Dodson \& Macphail, 2004). Many plant lineages that were once widespread within temperate Australia, now have separate taxa in the SouthWest and southeast/eastern Australia because of the biogeographical barrier imposed by aridification and the elevation of limestone sediments in the current Nullarbor Plain, beginning $14 \mathrm{Ma}$ (Crisp \& Cook, 2007).

\subsection{A Radiating and Hyperdiverse Flora}

Elements of the Australian flora were already present in the Upper Cretaceous, $90 \mathrm{Ma}$, mostly confined to rainforest dominated by conifers but also in fire-prone, sclerophyll pockets (see Fig. 1.5 - Proteaceae phylogeny). The large asteroid that struck the Earth in the Gulf of Mexico 65.5 Ma, causing an abrupt end to the Cretaceous Period, was an important event for the world's biota, including the SouthWest. Within 4 million years (61-62 Ma), key taxa in the SouthWest flora such as Banksia (Proteaceae), Eucalytpus (including Corymbia) (Myrtaceae) and the Australian Restionaceae emerged (Fig. 1.1). All these groups are adapted to nutrient-impoverished soils and highly fire-tolerant. Eucalypts are at present the dominant overstorey species in temperate Australian woodlands and forests and they further enhanced the flammability of the flora through the aromatic oils in their leaves and stems though it is thought that initially they evolved to deter herbivores (Crisp et al., 2011). Eucalypts also have a distinctive epicormic resprouting structure (Chapter 2; Burrows, 2013) that remained unchanged throughout the subsequent Cenozoic Era to the present time (Crisp et al., 2011). 


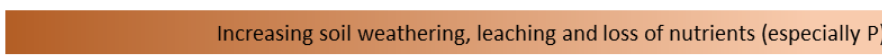

Increasingly flammable ecosystems

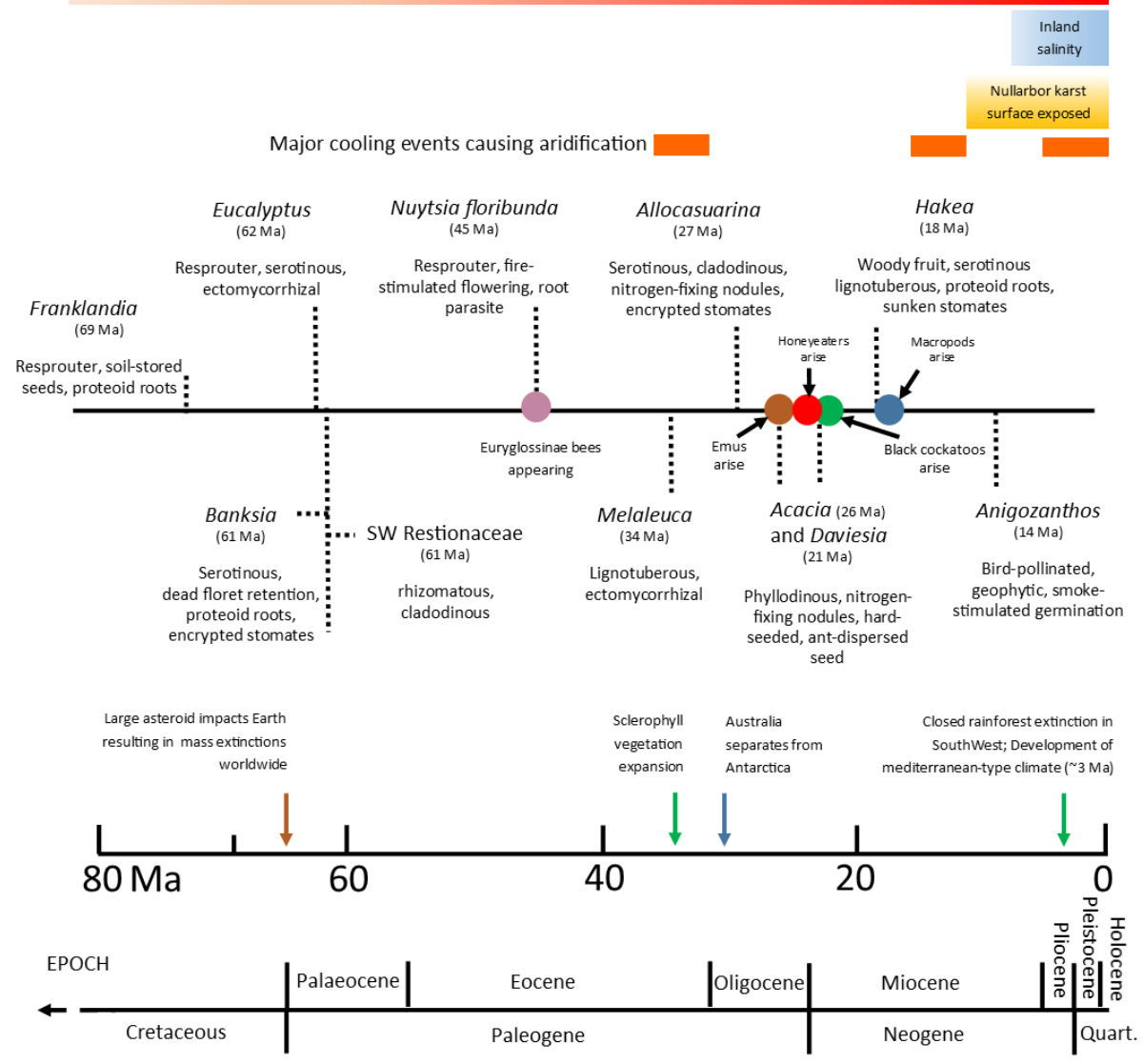

PERIOD

Fig. 1.1: Appearance of extant species-rich and iconic SouthWest taxa in Australia since the late Cretaceous Period compared with the occurrence of biotic and environmental agents of selection. Euryglossin bees and honeyeaters are pollinators of the flora (Chapter 8) whereas black cockatoos have influenced the evolution of woody-fruited species (e.g. Hakea) (Chapter 11). Geological time compiled from The Geological Society of America Geological Time Scale (2012, v. 4), and key events obtained from Byrne et al. (2014). Formation of Nullarbor Plain and aridification events since $35 \mathrm{Ma}$ obtained from Crisp \& Cook (2007). Information obtained from time-calibrated molecular phylogenies described in Crisp et al. (2004) [Allocasuarina]; Vidal-Russell \& Nickrent (2008a) [Nuytsia]; Hopper et al. (2009) [Anigozanthos]; Prideaux \& Warburton (2010) [Macropods]; He et al. (2011) [Banksia]; Crisp et al. (2011) [Eucalyptus, Melaleuca]; White et al. (2011) [Calyptorhynchinae cockatoos]; Miller et al. (2013) [Acacia]; Almeida et al. (2012) [Euryglossinae bees]; Litsios et al. (2013) [Restionaceae]; Baker et al. (2014) [emus]; Joseph et al. (2014) [honeyeaters]; Franklandia and Hakea from Fig. 1.5. 
Tree root-parasites are basal within the hemiparasitic Santalales order and the best known in the SouthWest is the monotypic Nuystia floribunda (Loranthaceae) that arose $45 \mathrm{Ma}$ during the Eocene (Fig. 1.1). This relict is unique among the Santalales in having wind-dispersed fruits (all others have succulent fruits that are a feature of rainforest species), precocious fire-stimulated flowering from fireblackened stems, tough, semi-terete leaves, and rhizomes reaching $100 \mathrm{~m}$ in length. These features suggest that at least parts of the SouthWest during the Eocene had a highly seasonal climate and were subject to frequent fire (Lamont \& He, 2012). Parasitism in the Loranthaceae evolved from terrestrial to aerial $28 \mathrm{Ma}$, with rapid diversification occurring during the Oligocene, an epoch of global cooling and temperate woodlands and grasslands (Vidal-Russell \& Nickrent, 2008a). Today Loranthaceae is dominated by aerial hemiparasites, though only Ameyma and Lysiana are present (and widespread) in the SouthWest (Chapter 5). Both genera are pollinated by honeyeaters (Meliphagidae) that originated $23.5 \mathrm{Ma}$ and radiated strongly between 15 to $5 \mathrm{Ma}$ (Joseph et al., 2014; Fig. 1.1). The frugivorous mistletoe bird (Dicaeum hirundinaceum, Dicaeidae) is a major seed disperser (Yan, 1993a), although this species did not colonise Australia until the Pleistocene, possibly as late as the Holocene (Reid, 1987), arriving from New Guinea and the surrounding islands (Nyári et al., 2009) and was already adapted to its mistletoe berry diet. This bird never reached Tasmania.

The Ecocene also saw the origin of solitary stingless bees in the Australian endemic subfamily Euryglossinae (Colletidae) (Fig. 1.1) and the Australian biodiverse subfamily Hylaeinae (48-54 Ma) (Almeida et al., 2012) that are important pollinators of small-flowered species in Australia. Emus (large flightless bird) (Dromaius novaehollandiae: Dromaiidae) appeared $27 \mathrm{Ma}$ (Fig. 1.1) and became important longdistance seed dispersers.

Major taxonomic groups were well established in the Australian flora by the time Antarctica split from Australia as it pulled north, beginning in the West in the early Eocene and finishing with Tasmania during the early Oligocene, leaving the flora to radiate in isolation from other continents, as the climate became colder and drier with Australia's drift into the mid-latitudes. The Casuarinaceae (Allocasuarina, Casuarina and Gymnostoma) radiated about $47 \mathrm{Ma}$ (Crisp, Cook \& Steane, 2004), with the Allocasuarina/Casuarina clade developing about $39 \mathrm{Ma}$, with their leaves reduced to minute scales, encrypted stomates hidden within cladodinous grooves, and serotinous woody cones (Crisp \& Cook, 2013). Speciation in Allocasuarina appears to have accelerated about 25 Ma dominating the expanding temperate sclerophyllous floras of the SouthWest and southeastern Australia (Crisp et al., 2004).

The greatest rates of speciation occurred during the long Miocene Epoch (Fig. 1.1), as the climate became drier and more seasonal. Rates of trait proliferation were highest in both directions at that time. For example, the rates of evolution of species with serotiny and non-serotiny, retention and shedding of dead florets and leaves, and clonality and non-clonality among the genus Banksia were greatest then 
(He et al., 2011). This indicates that a great range of habitats and climate extremes was present at that time and that the Miocene was an important period in the evolution of the SouthWest flora (and Australia generally). The only exception among banksias was the thickening of the mantle of dead florets that finally covered the fruits that peaked in the Pliocene (2-5 Ma), either as a response to increasing reliance on fire to melt the resin sealing the fruits or to improve crypsis from the increasing presence of granivorous black cockatoos (Chapter 10). The dominance of the Proteaceae within the SouthWest flora throughout much of the Cenozoic (Itzstein-Davey, 2007) is believed to have been a major contributor to the development of the iron/aluminium-rich lateritic soils here (Pate, Verboom \& Galloway, 2001) because of the long-term effect of the family's proteoid root clusters that exude organic acids to increase phosphorus uptake efficiency (Chapter 6) with subsequent mobilization and redeposition of iron/aluminium oxides at depth. The concreted laterite was subsequently exposed during the arid periods that followed as the surface sands were blown into the valleys (Glassford \& Semeniuk, 1995). During wetter periods even the upland laterite and underlying kaolinitic clay were sometimes washed away to expose the parent gneissic granite, to produce monadnocks that are also a feature of the SouthWest landscape.

The iconic and ecologically-important Australian and SouthWest genus Acacia (Fabacae: Mimosoideae) arose during the late Oligocene (Fig. 1.1). Originating $26 \mathrm{Ma}$ (Miller et al., 2013), Acacia has radiated to over 1000 extant Australian species, many in the SouthWest. Arid zone species related to A. victoriae and A. pyrifolia represent an early branch in the phylogeny of Australian acacias, although the estimated age of these taxa is less than 7 Ma (Miller et al., 2013). Acacia species possesses either bipinnate leaves or phyllodes (flattened petioles that function as leaves) in mature plants. All seedlings possess compound leaves which suggests that this is the ancestral leaf type. Bipinnate leaves occur in the sections Botrycephalae and Pulchellae and are rare compared with phyllodinous species that may dominate the driest parts of the SouthWest. The Pulchellae radiated 17-18 Ma, whereas the complex Botrycephalae/ Phyllodineae clade (where compound and phyllodinous species are interspersed) originated between 7.5 and 13.5 Ma and occurs in wetter areas (Miller et al., 2013). Phyllodes may be simple or fasciculate (clustered), although fasciculate species are not common (5\% of the genus) and not confined to any Section (Maslin, 2014). Another fabaceous genus, Daviesia, radiated $21 \mathrm{Ma}$, and consists of phyllodinous and cladodinous species and some species developed roots with anomalous secondary thickening (cord roots) (Pate et al., 1989; Crisp \& Cook, 2003).

Modern emus (Dromaius novae-hollandiae; Dromaiidae) appeared at $26 \mathrm{Ma}$ though their ancestors (even larger, flightless birds) can be traced to $78 \mathrm{Ma}$ (Baker et al., 2014). These voracious omnivores pluck foliage, flowers and fruits (and insects) from almost any plant available (Calvińo-Cancela et al., 2006) so they have probably had a role in the evolution of anti-herbivory traits, such as spiny leaves and mimicry. Interestingly, SouthWest emus have had sufficient time to develop immunity to the toxic fluoroacetates produced by many Gastrolobium species here 
(Chapter 8). Macropods evolved much later at 17 Ma (Prideaux \& Warburton, 2010) as the Miocene became drier and more open vegetation, especially grasslands, developed. Kangaroos and wallabies browse on a wide range of species and young plants in particular are highly vulnerable, especially if they are of above average height and have a grasslike appearance even when they are actually dicotyledons (Rafferty et al., 2005; Parsons et al., 2006; Rafferty \& Lamont, 2007). Chemical defences, such as phenolics (tannins), are effective at the seedling stage (Rafferty et al., 2005, 2010; Parsons et al., 2005; Parsons et al., 2006). Spinescence is only strongly developed in mature plants when it can be quite effective against kangaroos, preventing new axillary growth from being reached (Hanley et al., 2007). Thus, macropods may have been a selective force in the evolution of these traits over the last 15 million years. Interestingly, rat kangaroos (bettongs in the SouthWest) evolved much earlier at $28 \mathrm{Ma}$ (Prideaux \& Warburton, 2010). As essential dispersal agents of ectomycorrhizal spores of 'truffle' fungi (Lamont et al., 1985) they may have played a key role in the evolution of both plants (e.g. eucalypts, peas) and higher fungi here.

Hakea (Proteaceae) originated $18 \mathrm{Ma}$ (Fig. 1.1; 1.5) and is a genus of remarkable functional diversity, storing seeds in serotinous woody fruits held in a crown of broad (with or without leaf spines), needle-like (with apical spines) or strap-like leaves. We propose that black cockatoos have had an important role in leaf and fruit trait development to deter avian granivores that is explored in Chapters 9 and 11. Preliminary work on a time-calibrated Hakea phylogeny (T. He, unpublished) shows that needle-leaved species arose from broad-leaved ancestors $14 \mathrm{Ma}$ (consistent with decreasing rainfall and increasing pressure from large herbivores and granivores), and the extraordinarily large fruits of the $H$. platysperma and $H$. pandanicarpa clades evolved $10 \mathrm{Ma}$ (consistent with increasing black cockatoo activity). Bird (honeyeater) pollination arose 14 Ma from insect-pollinated ancestors (Hanley et al., 2009) at a time when these birds were beginning to radiate. Fruit mimicry appeared in the $H$. prostrata/ruscifolia and $H$. trifurcata/lasianthoides groups at about $7 \mathrm{Ma}$. H. clavata, with the thickest leaves of all sclerophyllous species anywhere in the world (4 $\mathrm{mm})$ and confined to rock crevices on monadnocks in the Esperance area, arose 6 Ma. Resprouting and serotiny are ancestral in Hakea evolving from a non-sprouting, nonserotinous lineage under rainforest conditions. Many of the most speciose extant SouthWest genera that diversified during the Miocene contain both fire-killed (but fire-stimulated germination) and resprouting species, supporting the importance of fire as an evolutionary force in the adaptive radiation of the SouthWest's hyperdiverse flora.

Arising in the mid-Miocene, Anigozanthos (Haemodoraceae) is the most striking herbaceous genus in the SouthWest ( $A$. manglesii is also Western Australia's floral emblem). Not only is it bird-pollinated (Hopper \& Burbidge, 1978), taking advantage of the honeyeaters now firmly established here, but its germination is stimulated by smoke, the active ingredient of which is glyceronitrile (Downes et al., 2014). 
Apart from the evergreen A. flavidus that occurs in wetlands, it usually dies back over summer-autumn. Most species are short-lived taking full advantage of the extra nutrients released after fire, and $A$. humilis will flower the first spring after fire.

\subsection{Evolutionary Constraints and Responses}

While currently poor soils, fire proneness, and seasonal aridity and high temperatures coincide in the SouthWest, it is difficult to separate primary from secondary constraints. However, we support the notion that nutrient impoverishment, especially of $\mathrm{P}$, was the instigator of change and that this had a subsequent cascading effect on other constraints. Greatest leaching and loss of P would have occurred from upland profiles exacerbated by closeness to the bedrock (gneissic granite is a poor source of mineral nutrients), strongly-leached, kaolinitc clay and subsurface laterite with $\mathrm{P}$ locked up in insoluble iron and aluminium oxides. Such sites also drain readily and, together with their shallowness, are more drought-prone. Reduced nutrient and water availability lead to smaller plant stature, a trend to evergreenness, and retarded litter decomposition rates. Leaves become increasingly scleromorphic and tannin-filled (primary effect), increasing their longevity and further reducing litter decomposition rates. Without a tree canopy cover, shrubs and small trees are more exposed to full sunlight and higher temperatures. Drought and heat adaptations develop as secondary effects.

Not only are drier, finer foliage and greater litter accumulation more flammable but exposure on uplands makes the vegetation more vulnerable to lightning strikes. Fire adaptations appear as secondary effects. With time, leaching, seasonality and aridity became more generally distributed and the sclerophyllous flora spread over the entire SouthWest. Such traits as carnivory, parastisim, geophyty (retreating to dormant underground structures in summer) and clonality become more common. The temperate rainforest disappeared by the late Pliocene, never to return (unlike eastern Australia).

In a similar way the switch from insect to bird and mammal pollination is a secondary effect that takes advantage of the introduction of more efficient pollinators. Spinescence, crypsis, woody fruits and long-distance dispersal are secondary responses to the later introduction of such formidable omnivores as emus, kangaroos and cockatoos.

Functionally the extant SouthWest flora is extraordinarily diverse with dominant genera developing distinct (and characteristic) traits to survive and compete in what is an overall harsh and climatically-diverse biome (Beard, 1984). Within a given plant attribute, taxa can be placed along a low to high cost gradient or economic biospectrum (Fig. 1.2). The concept that plant traits occur along economic biospectra was proposed by Wright et al. (2004) based on the occurrence of worldwide trade-offs in leaf attributes from 'low cost' (thin, soft leaves with a short leaf lifespan) to 'high cost' (thick, hard leaves with a long leaf lifespan) (Fig. 1.2), also known as 'fast-slow' trade-offs at the 
leaf, stem and root levels (Reich, 2014). Part of the problem with the concept is that costs and benefits cannot be assessed using the same 'currency'. Also costs depend on the currency under consideration. Note for example that scleromorphic leaves are a high cost in terms of carbon but not of $\mathrm{N}$ and $\mathrm{P}$ and that the benefits in terms of increased fitness far outway the costs of production. These biospectra provide an additional framework that can be used to investigate the significance of broad-scale plant responses to current and past evolutionary pressures.

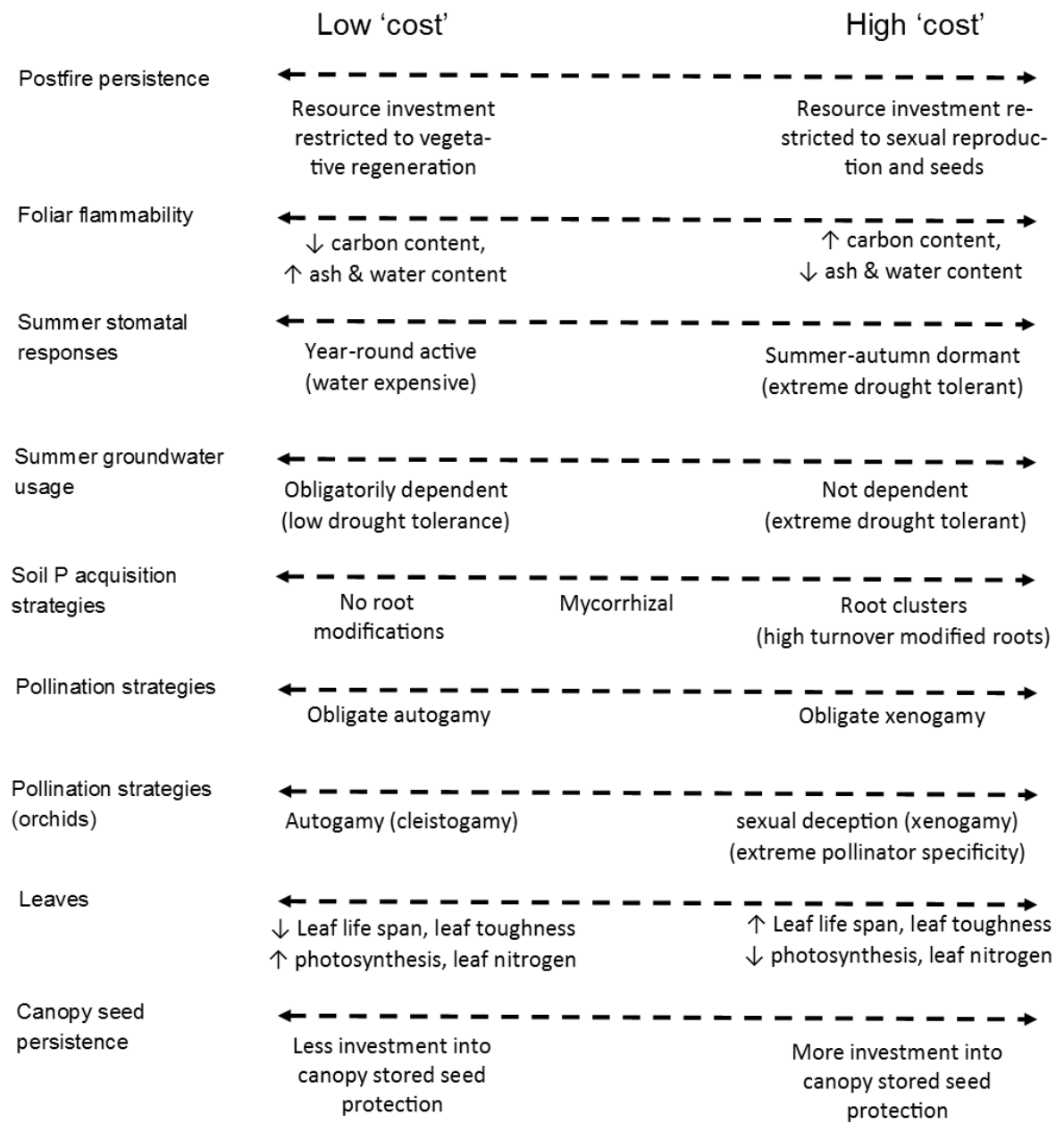

Fig. 1.2: Trait economic biospectra they relate to the SouthWest flora. The term 'cost' implies an adaptive or evolutionary trade-off between form (i.e. morphology) versus function as described in this book. Traits are not necessarily related, nor is the 'cost' involved similar between traits. 


\subsection{The SouthWest Flora 45 Million Years Ago and Now}

The Early to Mid-Eocene, 45-56 Ma, was one of the hottest and wettest periods in the Earth's history and the seas and oceans rose up to $140 \mathrm{~m}$ above their present levels. Much of the coastline of the SouthWest was flooded for up to $300 \mathrm{~km}$ inland and the present Nullarbor Plain was occupied by a huge inland sea, such that several major rivers flowed eastwards into it.

One of those was the Lefroy River system that today only exists as a series of salt lakes. This was an ideal environment for sedimentation and the Eocene mudstones have proved a rich source of pollen (palynomorphs) (Itzstein-Davey, 2007). Table 1.1 gives the results of much painstaking work on identifying the plant taxa present from their pollen, compared with their current presence elsewhere in Australia.

None of the species recorded currently exists at the Lefroy River site as it is now far too dry and saline. The vegetation was a mixture of subtropical and temperate rainforest, dominated by deciduous Nothofagus (Fig. 1.3) and sclerophyllous woodland and shrublands dominated by eucalypts but especially many genera of Proteaceae. Indeed, the Proteaceae accounted for a mean of 34\% of all pollen (when the windpollinated Nothofagus was omitted), with species richness values comparable with those in SouthWest scrub-heath today. Of the 28 rainforest taxa, 21 have become extinct in southwestern Australia (though eight still exist in the Kimberley) but 15 of the 16 hard-leaved taxa remain and have speciated greatly since then. In contrast, 26 of the 28 rainforest taxa still occur in eastern Australia, as well as all the sclerophylls, but they have speciated less.

The transformation from a predominately rainforest flora to hyperdiverse temperate woodlands and shrublands (Fig. 1.3) due to increased aridity during the Miocene and Pliocene (Byrne et al., 2011) resulted in the SouthWest flora exhibiting morphological and physiological traits more suitable for seasonally dry Mediterranean-type environments (Table 1.2). About a third of Australia's total $(8,500)$ occurs in southwestern Australia, currently the Mediterranean-climate corner, though it only occupies $5 \%$ of the Australian continent. 

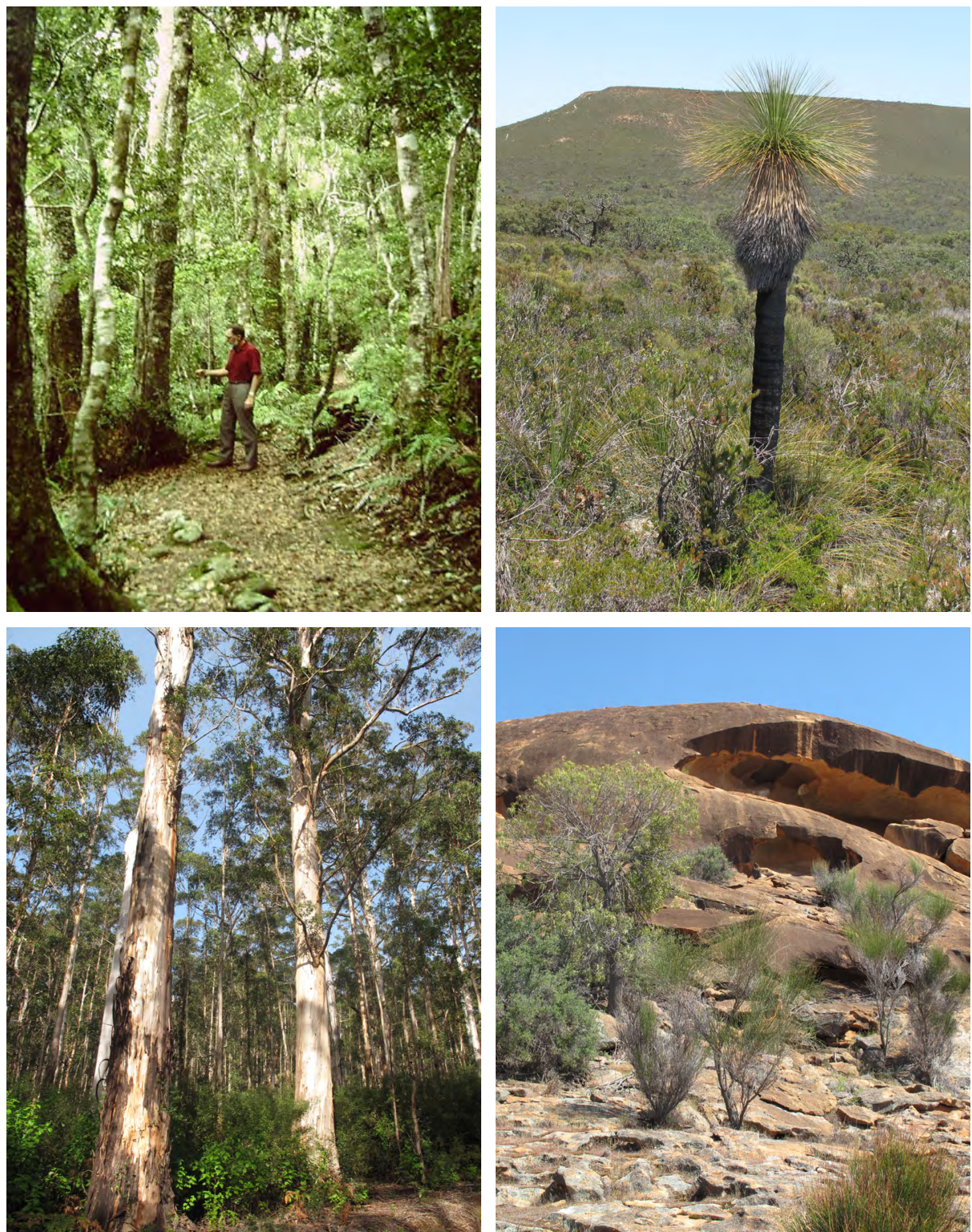

Fig. 1.3: (upper left) Nothofagus moorei forest in uplands of the Lamington Plateau, Queensland. Similar fire-free, temperate rainforests were the dominant vegetation type over much of Australia, including the SouthWest, during the Palaeogene. (upper right) Present day sclerophyllous scrubheath vegetation of the sandplains of the SouthWest with Mt Lesueur in the background and the grasstree, Xanthorrhoea drummondii, in the foreground. (lower left) Eucalyptus diversicolor (karri) forest is confined to the present day wetter areas of the SouthWest. (lower right) outcrops of gneissic granite provide refugia for plants from fire but increased exposure to drought and summer heat. 
Table 1.1: Soft- and hard-leaved plant taxa occurring in the Early to Mid-Eocene, 40-56 Ma, according to pollen samples collected from the Lefroy River system, southwestern Australia, compared with their current presence and occurrence elsewhere in Australia. Data collated by Byron Lamont from Hos (1975), Itzstein-Davey (2004), Florabase and Flora of NSW.

\begin{tabular}{|c|c|c|c|c|}
\hline Leaf type & $\begin{array}{l}\text { Modern taxon } \\
\text { equivalent }\end{array}$ & Common name & $\begin{array}{l}\text { Still present in } \\
\text { SouthWest? }\end{array}$ & $\begin{array}{l}\text { Present } \\
\text { in Eastern } \\
\text { Australia? }\end{array}$ \\
\hline \multirow{21}{*}{$\begin{array}{l}\text { Soft-leaved } \\
\text { (closed forest) }\end{array}$} & Beauprea & Protea family & no (New Caledonia) & no \\
\hline & Adansonia & Sausage tree & no (Kimberley) & no \\
\hline & Nothofagus (dominant) & Southern beech & no & yes \\
\hline & Araucaria & Conifer & no & yes \\
\hline & Agathis & Conifer & no & yes \\
\hline & Dacrydium & Conifer & no & yes (Tas) \\
\hline & Microcachrys & Conifer & no & yes (Tas) \\
\hline & Livistona & Palm & no (Kimberley) & yes \\
\hline & Ficus & Fig & no (Kimberley) & yes \\
\hline & Ilex & Holly & no (Kimberley) & yes (Qld) \\
\hline & Musgraveinae & Protea family & no & yes \\
\hline & Anacolosa & Galonut (India) & no (Olax related) & yes \\
\hline & Sonneratia & Mangrove & no (Kimberley) & yes \\
\hline & Symphionema & Protea family & no & yes \\
\hline & Lomatia & Protea family & no & yes \\
\hline & Gleichenia & Scrambling fern & no & yes \\
\hline & Cyathea & Tree fern & no & yes \\
\hline & Eugenia/Syzygium & Myrtle & no (Kimberley) & yes \\
\hline & Sapotaceae & Native plum & no (Kimberley) & yes \\
\hline & Polypodiaceae & Epiphytic fern & no (Kimberley) & yes \\
\hline & Lycopodium & Clubmoss & no & yes \\
\hline \multirow{5}{*}{$\begin{array}{l}\text { *possibly Nuytsia } \\
\text { as no other mistletoe } \\
\text { existed then }\end{array}$} & Loranthaceae* & Mistletoe & yes & $\begin{array}{l}\text { yes } \\
\text { (not Nuytsia) }\end{array}$ \\
\hline & Hibiscus & Hibiscus & yes (Eremean) & yes \\
\hline & Dennstaedtiaceae & Bracken fern & yes & yes \\
\hline & Selaginella & Clubmoss & yes (1 sp) & yes \\
\hline & Podocarpus & Conifer & yes (1 sp) & yes \\
\hline
\end{tabular}


Table 1.1: Soft- and hard-leaved plant taxa occurring in the Early to Mid-Eocene, 40-56 Ma, according to pollen samples collected from the Lefroy River system, southwestern Australia, compared with their current presence and occurrence elsewhere in Australia. Data collated by Byron Lamont from Hos (1975), Itzstein-Davey (2004), Florabase and Flora of NSW.

\begin{tabular}{|c|c|c|c|c|}
\hline Leaf type & $\begin{array}{l}\text { Modern taxon } \\
\text { equivalent }\end{array}$ & Common name & $\begin{array}{l}\text { Still present in } \\
\text { SouthWest? }\end{array}$ & $\begin{array}{l}\text { Present } \\
\text { in Eastern } \\
\text { Australia? }\end{array}$ \\
\hline \multirow{2}{*}{$\begin{array}{l}\text { \#1 location near } \\
\text { Denmark }\end{array}$} & Sphagnum & Peat moss & yes (1 sp)\# & yes \\
\hline & Cunoniaceae & - & $\begin{array}{l}\text { yes - Aphanope- } \\
\text { talum }\end{array}$ & yes \\
\hline \multirow{7}{*}{$\begin{array}{l}\text { Hard- leaved } \\
\text { (woodland, } \\
\text { shrubland) }\end{array}$} & Banksia & Protea family & yes (abundant) & yes \\
\hline & Adenanthos & Protea family & yes (abundant) & yes (rare) \\
\hline & Hakea/Grevillea & Protea family & yes (abundant) & yes \\
\hline & Lambertia & Protea family & yes & yes \\
\hline & Petrophile & Protea family & yes (abundant) & yes \\
\hline & Synaphea & Protea family & yes (abundant) & yes \\
\hline & Xylomelum & Protea family & yes & yes \\
\hline \multirow[t]{9}{*}{ + unidentified } & $\begin{array}{l}\text { Many other } \\
\text { Proteaceae + }\end{array}$ & Protea family & yes & yes \\
\hline & Eucalyptus & Myrtaceae & yes (abundant) & yes (abundant) \\
\hline & Angophora & Myrtaceae & no & yes \\
\hline & $\begin{array}{l}\text { Other capsulate Myr- } \\
\text { taceae }\end{array}$ & Myrtaceae & yes (abundant) & yes (abundant) \\
\hline & (Allo)Casuarina & She-oak & yes (abundant) & yes \\
\hline & Macrozamia & Cycad & yes & yes \\
\hline & Ericaceae & Epacrid & yes (abundant) & yes (abundant) \\
\hline & Dodonaea & Hopbush & yes (abundant) & yes (rare) \\
\hline & Beyeria & $\begin{array}{l}\text { Turpentine } \\
\text { bush }\end{array}$ & yes (abundant) & yes (rare) \\
\hline
\end{tabular}


Table 1.2: Generalised shifts in Angiosperm form and function in the SouthWest flora from a predominantly rainforest environment (Cretaceous/Palaeogene) to a predominantly woodland environment (Neogene/Quaternary).

\begin{tabular}{ll}
\hline Rainforest (closed vegetation) & Woodland (open vegetation) \\
\hline Drought-sensitive (mesophytes) & Drought-tolerant (xerophytes) \\
Leaves thin, light, moist (mesophylls) & Leaves thick, dense, dry (sclerophylls) \\
\hline Fire-sensitive & Fire-tolerant \\
High-nutrient requiring & Low-nutrient tolerant \\
Salt-sensitive (glycophytes) & Salt-tolerant (halophytes) \\
\hline Single-stemmed (tree) & Multi-stemmed (mallee) \\
Thin barked & Thick barked \\
Loss of leaf bases & Retention of leaf bases (e.g. Dasypogon) \\
Shoots of equal size & Long and short shoots (heteroclady) (e.g. Allo- \\
\hline casuarina) \\
\hline Plants large, fast growers & Plants small, slow growers \\
Tree ferns & Grasstrees (Xanthorrhoea) \\
Herbs aerially located & Herbs terrestrial (e.g. orchids) \\
Wood poorly lignified (soft) & Wood highly lignified (hard) \\
Growth non-seasonal & Growth seasonal \\
\hline Leaves horizontal, stomates on one side (bifacial) & $\begin{array}{l}\text { Leaves vertically twisted (tips pointing upwards) } \\
\text { or erect, stomates on both sides (isobilateral) } \\
\text { Leaves rolled at edges (ericoid) or circular in } \\
\text { cross section (terete) }\end{array}$ \\
Leaves flat & Stems with cladodes, phyllodes or phylloclades \\
\hline Stems with leaves & Fruits woody, dehiscent (e.g. Myrtaceae) \\
\hline Fruits succulent, indehiscent & Seeds with elaiosomes (e.g. legumes) \\
Seeds without ant-attracting arils (elaiosomes) & Plants unpalatable \\
\hline & Tannins, essential oils and resins abundant \\
\hline
\end{tabular}

\subsection{A Relict Podocarp}

Podocarpaceae is an ancient conifer family that had its origins 240 million years ago (Triassic) though the modern species had their origins more recently, 125 million years ago. They were widespread in Australia in the Cretaceous and Paleogene and ten species still occur here, all but two in rainforests on the east coast. The only survivor in the SouthWest is Podocarpus drouynianus that occurs in the jarrah forest (Fig. 1.4). 
It would have been eliminated along with the other rainforest species in the drier late Neogene-Quaternary but for the possession of two special features: 1) it is a rhizomatous shrub (all but one other species are substantial trees) that survives fire and moreover, coning is stimulated by fire (Chalwell \& Ladd, 2005; Ladd \& Enright, 2011); and 2) it has exceptionally narrow, ribbed, glaucous and semi-erect leaves that, combined with its compact, low-lying growth form, appear to increase its drought tolerance compared with other podocarps. So $P$. drouynianus is a relict from wetter times only surviving because it is well matched to its current mediterranean climate and frequent fire.

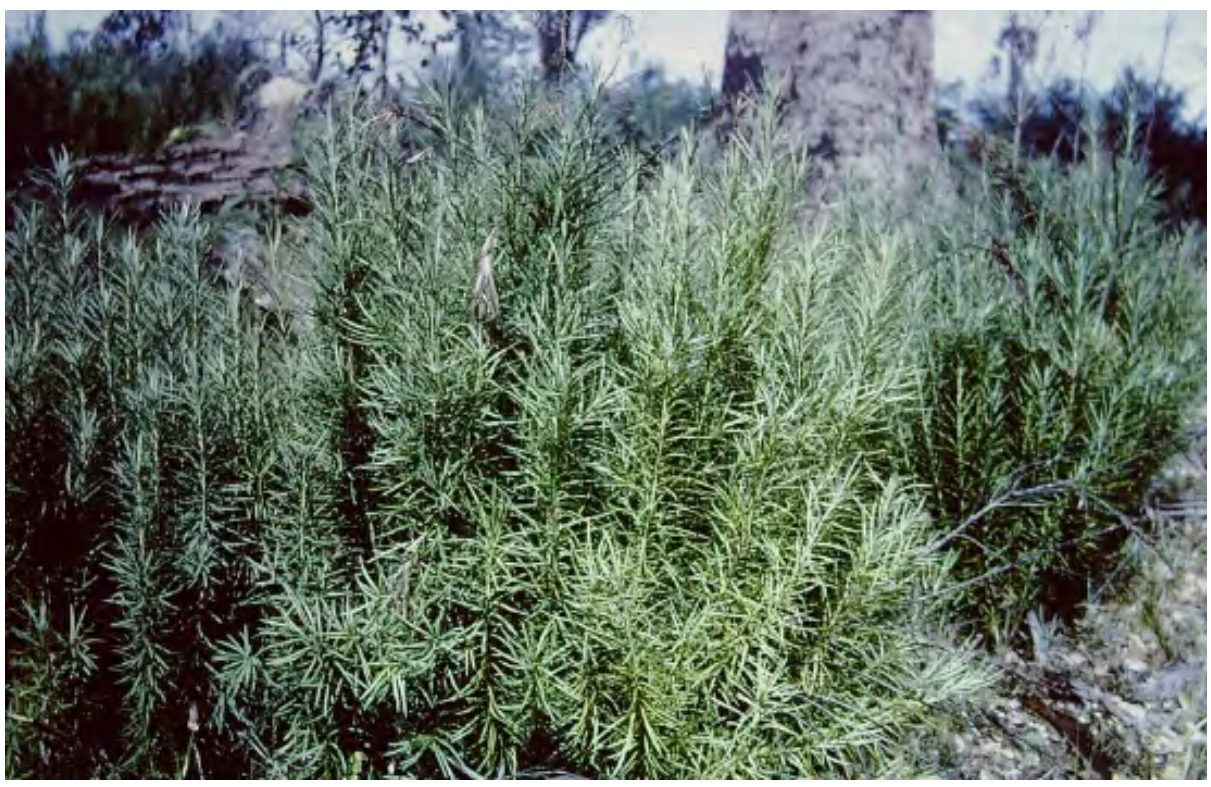

Fig. 1.4: Podocarpus drouynianus (Podocarpaceae) is a rhizomatous shrub, $75 \mathrm{~cm}$ tall, and restricted to the higher rainfall areas of SouthWest's jarrah forests. $P$. drouynianus is uniquely fire- and drought-tolerant among podocarps that normally exist as trees in rainforest throughout the Southern Hemisphere.

\subsection{Fire and Evolution of the Proteaceae}

A time-based phylogeny for one of the most prominent plant families in the Southern Hemisphere, the Proteaceae, is presented in Fig. 1.5. The Proteaceae is especially well represented in the SouthWest flora with 800 extant species. The phylogeny was created by comparing parts of the DNA structure for species in all genera in the family to show their phylogenetic relationships independent of their morphological relationships (called a molecular phylogeny; see Lamont \& He (2012) for more details). 
The dates for seven well-chronicled fossils (preserved leaves and pollen) scattered through the geological record were compared with differences in DNA structure through the phylogeny to create a molecular clock (from left to right) for the stems of each lineage (line of descent) and thus a chronogram for the evolution of the entire family.

Whether each genus occurs in fire-prone environments is given in red, or nonfire-prone (usually rainforest) environments is given in green. The three genera in eastern Australia with species in both are given in alternating red and green. The genera were then progressively fused from right to left using the seed-storage and fire-environment criteria in separate analyses, using a technique called the Bayes Markov Chain Monte Carlo procedure, to reconstruct ancestral traits in the family. The closely related Sabiaceae, Nelumbo (Nelumbonaceae) and Platanus (Platanaceae) were used as a reference group in the chronogram for the Proteaceae.

The chronogram shows that the Proteaceae arose 115 Ma with the oldest clades appearing $94 \mathrm{Ma}$. This makes it one of the oldest flowering plant families known. The Proteaceae soon separated into two further groups that are by far the most speciose today, the subfamilies Grevilleoideae and Proteoideae. Basal lineages, such as Placospermum, Agastachys/Symphionema, Carnarvonia and Macadamieae, arose 80-90 Ma in rainforest and still occur there along the eastern border of Australia.

However, the Proteoideae arose in a fire-prone environment $90 \mathrm{Ma}$ (Fig. 1.5) and speciated strongly once its ancestor left the rainforest, giving rise to such major sclerophyllshrub genera as Petrophile (49 Ma), Conospermum/Synaphea (36 Ma) and Adenanthos (34 Ma) now accounting for 250 species in the SouthWest flora. Fire-adapted lineages arose much more slowly and fitfully in the Grevilleoideae, with the major sclerophyll shrub/tree genera, Banksia (61 Ma) and subgenus Dryandra (23 Ma), Hakea (18 Ma) and Grevillea (11 Ma) now accounting for over 500 species in the SouthWest flora.

By $81 \mathrm{Ma}$, fire-adapted traits had begun to appear. In particular, the Petrophile lineage evolved with the ability to hold its fruits in a woody cone until released by fire heat (serotiny). Conospermum/Franklandia and Adenanthos appeared with the ability to store single-seeded fruits in the soil until cued to germinate by smoke. A refinement at 44.5 Ma was the development of arils (elaiosomes) on the diaspores that attract ants that bury them to an ideal depth for receiving a fire heat/smoke pulse to stimulate germination. This is one of the earliest records for elaisome-bearing seeds or fruits (diaspores) known. Serotiny first appeared among the Grevilleoideae 61 Ma via Banksia, followed later by three other serotinous lineages. Fire-enhancing traits, such as the retention of dead leaves by Banksia bella (= Dryandra pulchella) (Fig. 1.6) first appeared $26 \mathrm{Ma}$ in the Banksia clade. Grevillea, which originated much later, is the only taxon in Proteaceae with seeds (rather than fruits) bearing arils or palatable wings, and is one of the most speciose genera in the Australian flora, third only to Acacia and Eucalyptus.

All of these fire-related traits are highly correlated through time with the occurrence of fire and, coupled with their fitness benefits in the presence of fire, confirm their place as important fire adaptations in the SouthWest flora. 


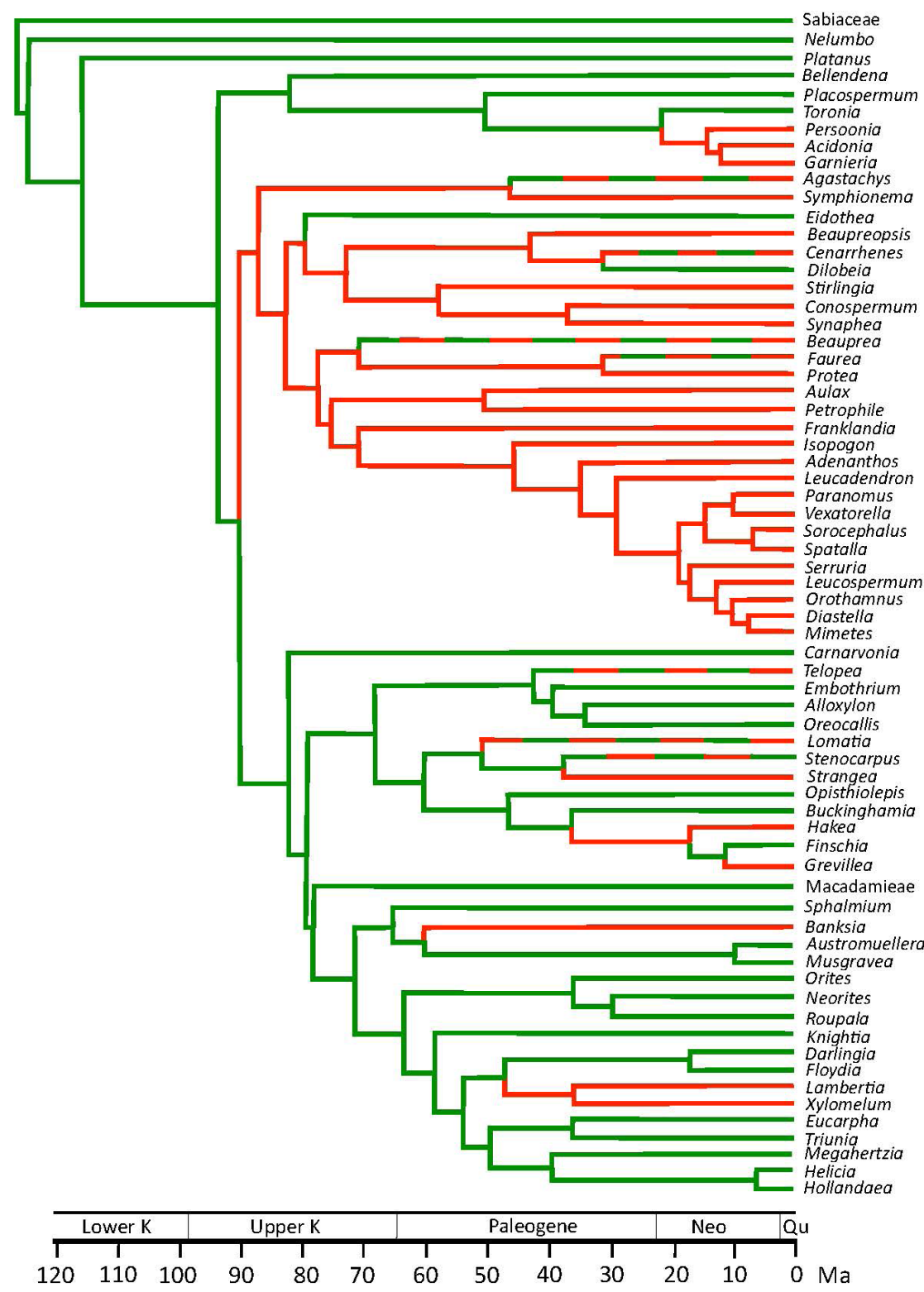

Fig. 1.5: Chronophylogeny of extant genera in the Proteaceae family. Adapted from Lamont and He (2012) based on data obtained from Sauquet et al. (2009). Genera and lineages that currently occur in fireprone floras are given in red, with broken lines indicating lineages with both extant rainforest and

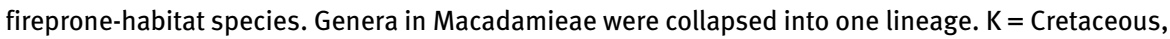
Neo = Neogene, $\mathrm{Qu}=$ Quaternary. SouthWest genera include Persoonia, Acidonia (endemic) Stirlingia (endemic), Conospermum, Synaphea (endemic), Petrophile, Isopogon, Franklandia (endemic), Adenanthos, Strangea, Hakea, Grevillea, Banksia, Lambertia and Xylomelum. 

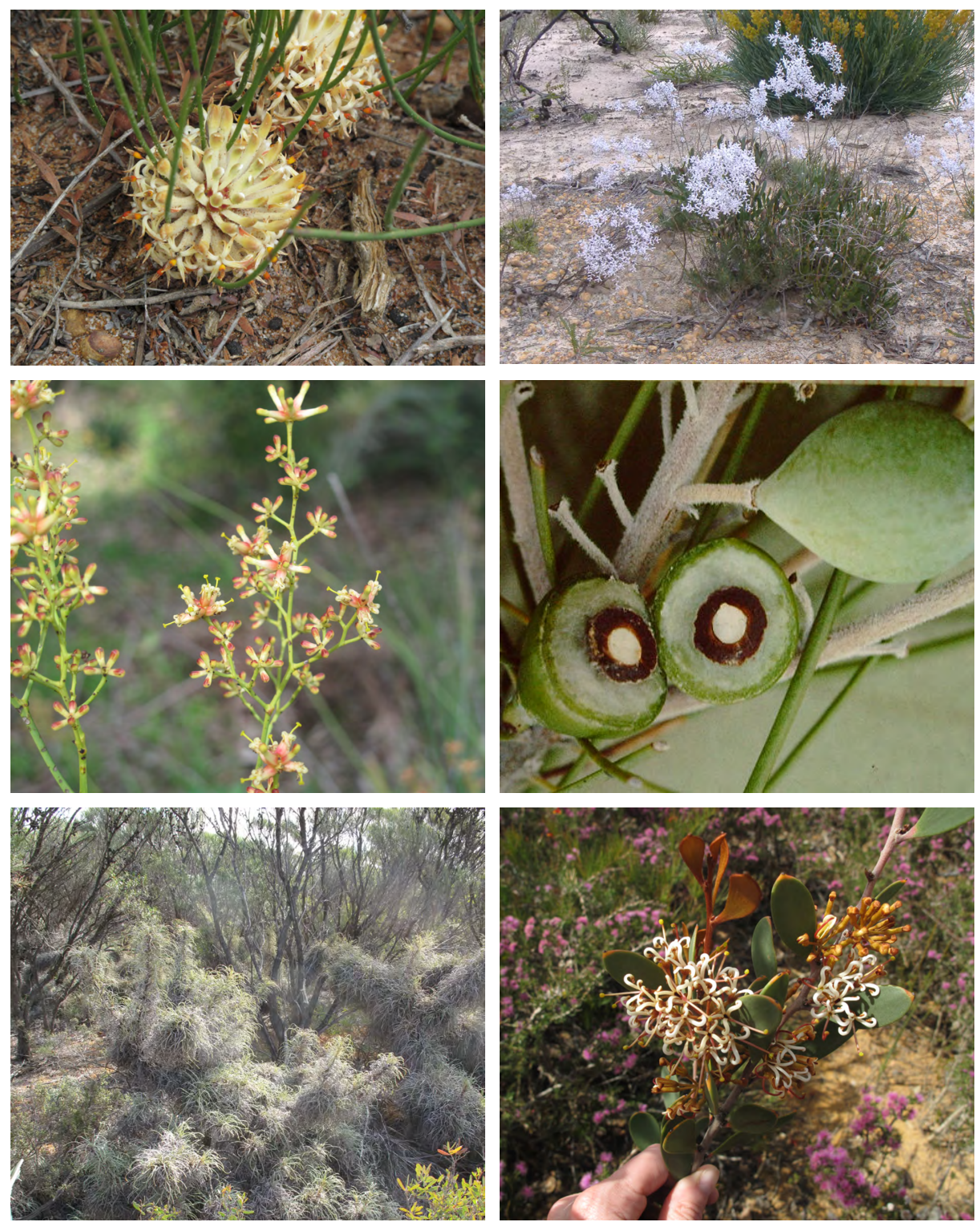

Fig. 1.6: Some species in the family Proteaceae. (top left) Petrophile longifolia (Proteaceae, subfamily Proteoideae) $30 \mathrm{~cm}$ tall, unlike other members of the genus bears its flowers just above the ground. (top right) Conospermum stoechadis (Proteoideae). Plant is $60 \mathrm{~cm}$ tall. (middle left) Stirlingia latifolia (Proteoideae) bearing male and bisexual flowers, $8 \mathrm{~mm}$ long. (middle right) Persoonia saccata (Persoonioideae), drupes $1 \mathrm{~cm}$ wide. Species with succulent fruits have rainforest affinities and are now rare in the SouthWest flora. (lower left) Banksia bella (previously Dryandra pulchella) (Grevilleoideae), a species that retains its dead foliage. This fire-enhancing trait first appeared 26-16 Ma (Miocene) in Banksia with the onset of seasonal drought and thus more frequent fire (He et al., 2011). Plants are $2 \mathrm{~m}$ tall. (lower right) Hakea pandanicarpa (Grevilleoideae). Individual flowers are $1.5 \mathrm{~cm}$ long. Note ferruginous new growth due to the dense indumentum of orange hairs. 


\subsection{Floristics and Phytogeography}

There are over 1,400 genera of flowering plants, 7 Gymnosperm genera and 44 fern genera currently recognised as occurring in Western Australia. Over 7,100 named taxa are now known to occur within southwestern Australia, and the actual number could be as high as 8,500 . More than 250 new plant species in the SouthWest were discovered and named in 2013 alone. In 1989, 3,560 plant taxa were recognised as occurring in Western Australia. This marked increase over the last 30 years can be accounted for by improved accessibility into more remote parts of the State, an increase in the number of botanical surveys and the continual taxonomic re-examination and reclassification of the flora at the genus and species levels.

Western Australia can be divided into 26 vegetation regions (phytoregions) that are based on differences in climate, soils and physiography (Fig. 1.7). The boundaries of these regions have been incorporated into an Interim Biogeographic Regionalisation for Australia (IRBA) (Australia's Bioregions, 2014). The IRBA bioregions and subregions currently used are the reporting unit for assessing the status of natural ecosystems, their protection in Australia's national reserve system and are also used as the monitoring and evaluation framework for the Australian Government's current Natural Resource Management initiatives.

These phytoregions are grouped into three Botanical Provinces: the Northern Province (the Kimberley); Eremaean Province (the desert interior, Murchison, Pilbara and Gascoyne) and the SouthWest Province. An additional zone, known as the SouthWest Interzone, is considered by some to be part of the Eremaean Province.

The concept of a southwestern Australian bioregion was first developed by Ferdinand von Müller in 1877 and subsequently discussed in detail in Ludwig Diels book The Plant Life of Western Australia South of the Tropics in 1906. In 1944, Charles Gardner (Western Australia's Government Botanist, 1929-1960) published a paper entitled The vegetation of Western Australia with special reference to climate and soils that expanded upon Diels' work in documenting the State's phytogeographic regions.

John Beard, inaugural director of Kings Park and Botanic Gardens in Perth, undertook the project of mapping Western Australia's vegetation from 1965 to 1985. This involved extensive field surveys and mapping from aerial photography that further refined the main state botanical regions (Beard, 1980) (see Fig. 1.7 and Table 1.3). 


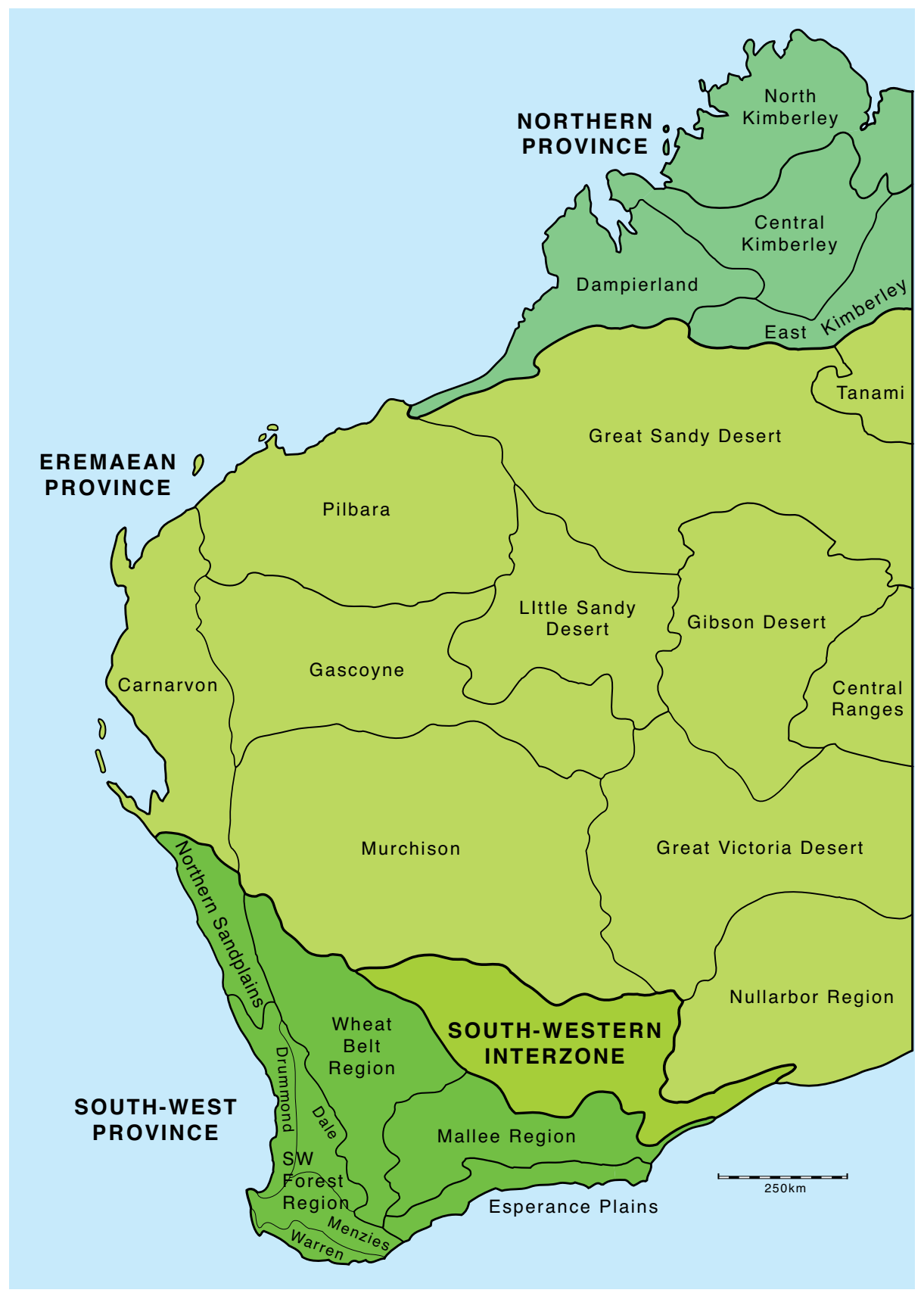

Fig. 1.7: Phytoregions of Western Australia (SouthWest coloured in dark green). See Table 2.3 for descriptions of the SouthWest phytogregions (after Beard, 1990). 


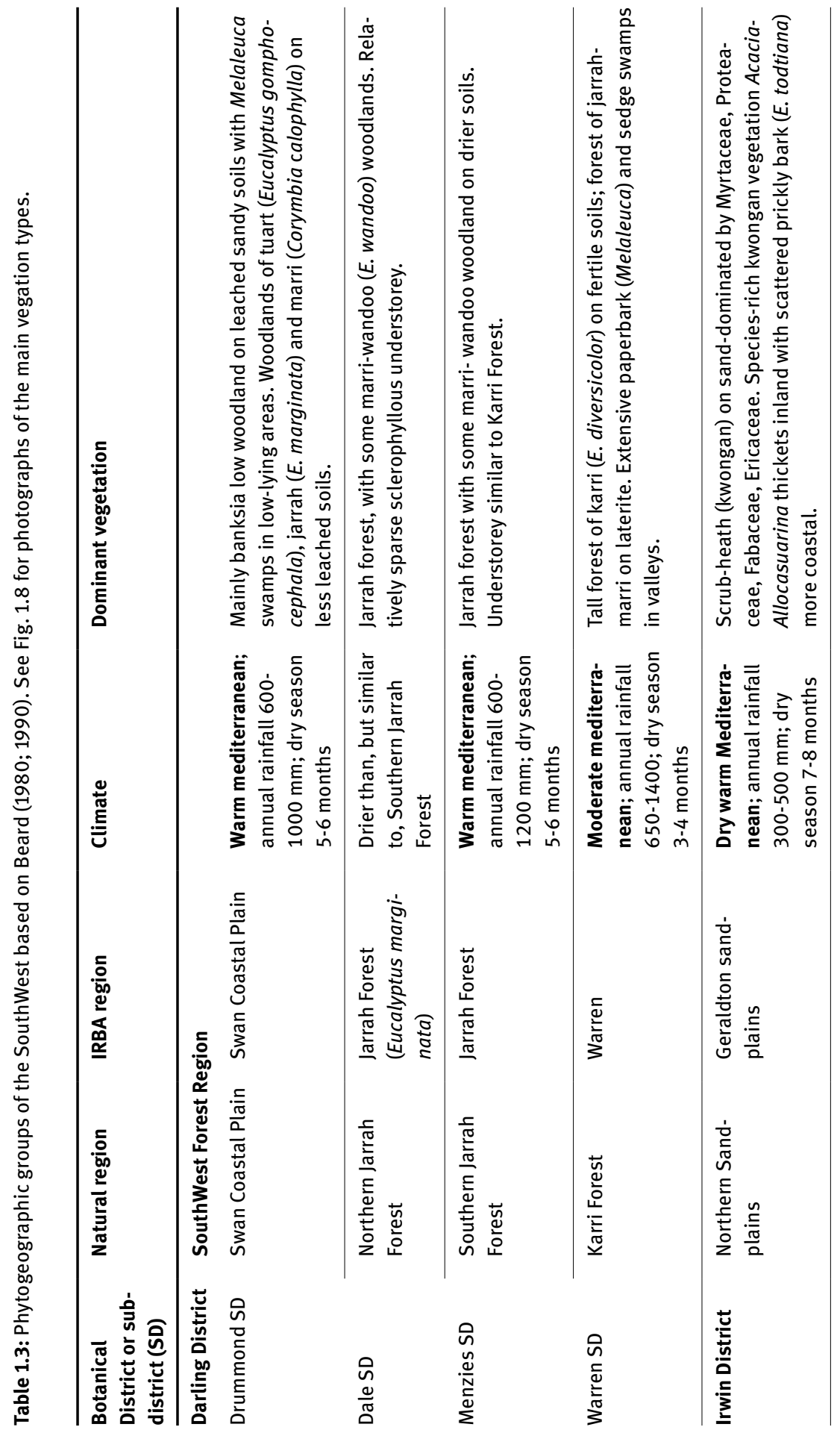




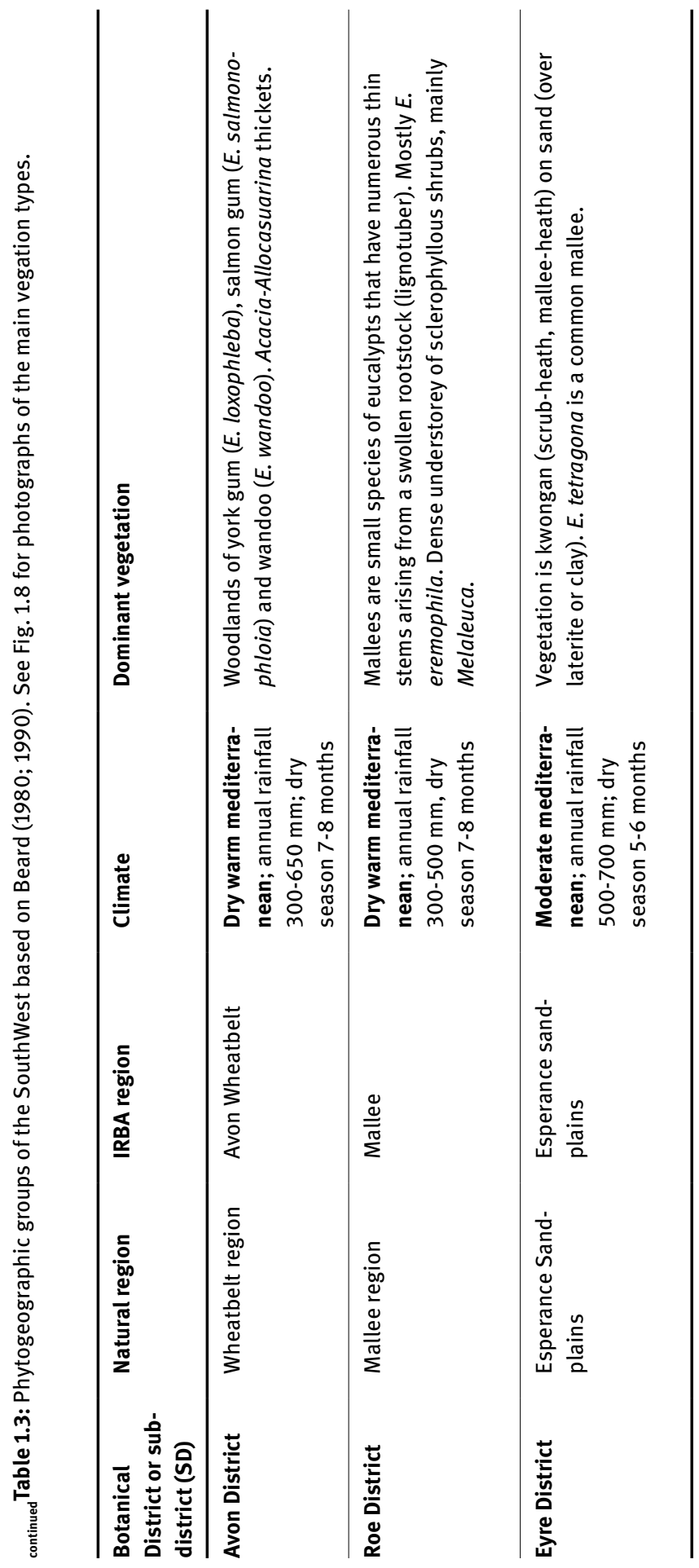



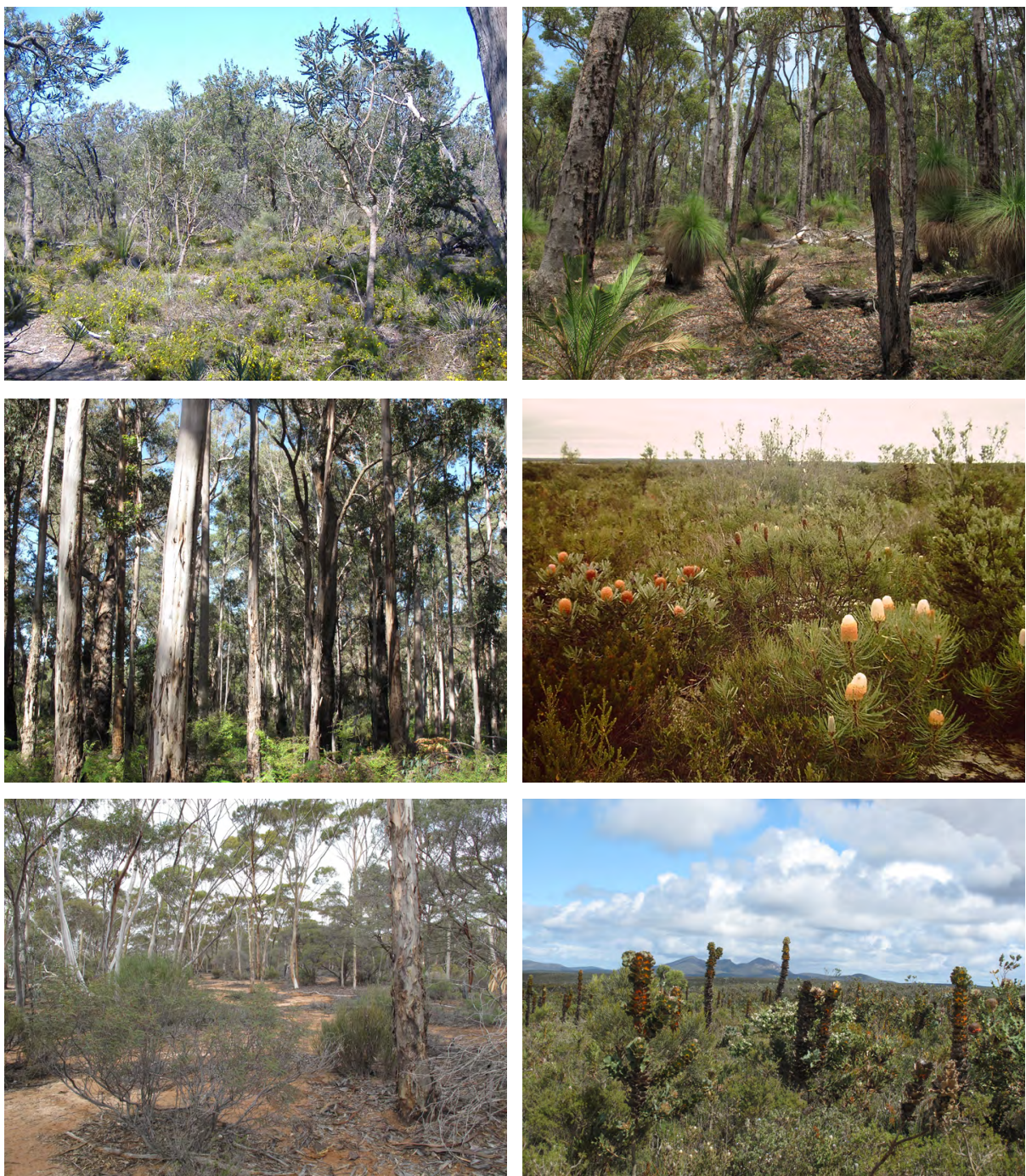

Fig. 1.8: (upper left) Banksia woodland of the Swan Coastal Plain (Drummond Subdistrict), with Banksia attenuata and B. menziesii co-dominating the overstorey, with scattered $B$. ilicifolia and jarrah (Eucalyptus marginata, far right). Hibbertia hypericoides (Dilleniacee) is in flower in the low shrub layer. (upper right) Jarrah forest of the Darling Scarp (Dale Subdistrict), $50 \mathrm{~km}$ southeast of Perth. (middle left) tall karri (Eucalyptus diversicolor) forest of the Warren Subdistrict. (middle right) Species-rich shrubland (scrub-heath) in the northern sandplains (Irwin District) near Eneabba with 1.5-m-tall Banksia menziesii in flower (left) and B. hookeriana (right) with non-flowering B. attenuata in between. 113 perennial species were recorded in a $40 \times 40 \mathrm{~m}$ plot at this site (Herath et al., 2009). (lower left) Mixed eucalypt woodland of the Wheatbelt (Avon District) is now confined to isolated reserves and roadsides. Pictured is a salmon gum woodland (Eucalyptus salmonophloia). (lower right) Species-rich shrublands of the sandplains surrounding the Barren Range, with the iconic erect Hakea victoria (Proteaceae) standing $2.5 \mathrm{~m}$ tall in the mid-foreground. 


\subsection{The SouthWest as a Biodiversity Hotspot}

The uniqueness of modern day SouthWest flora is well recognised and documented, and is a major biodiversity hotspot, globally and within Australia (Hopper \& Gioia, 2004). The definition of a hotspot is an area that contains at least $0.5 \%$ (or 1,500) of the world's plant species as endemic and whose biota is under threat from human activity, such as land clearing (Myers et al., 2000). The only Australian hotspot that meets these criteria is southwestern Australia.

The flora is both species and phylogenetically rich at both the regional and landscape levels (Sauquet et al., 2000; Hopper \& Gioia, 2004; Merwin et al., 2012), and contains numerous endemic genera and species (Hopper \& Gioia, 2004) some of which represent ancestral forms of pandemic families (e.g. Nuytsia; Hopper, 2010) and ancient lineages (e.g. order Dasypogonales and family Cephalotaceae). The most species-rich plant families and genera are listed in Table 1.4.

For example, the high-rainfall karri forest communities contain local endemic forest eucalypts (the tingles - Eucalyptus brevistylis, E. jacksonii, E. guilfoylei and the red-flowering gum, Corymbia ficifolia) that are considered relictual biota of past wetter climates that are restricted to the southern coast of the SouthWest (WardellJohnson \& Coates, 1996). Another endemic relict, Cephalotus follicularis (Albany pitcher plant), is restricted to wetlands and fringes of bogs and drainage ditches. These forested regions have one of highest levels of orchid species richness in the SouthWest (Phillips et al., 2011).

This extraordinary species richness is reflected in the multitude of morphologies and physiological processes evolved at the genus, species, community and ecosystem levels that maintain population survival and expansion in their nutrient-impoverished, seasonally dry and fire-prone landscapes. Traits may vary both along environmental gradients and among species occupying similar habitats (Lamont et al., 2002; Ackerly \& Cornwell, 2007), and are the foundations for understanding adaptive responses to past, present and future changing climates (Esther et al., 2010).

Among the world's five Mediterranean-type climates, the SouthWest region is topographically unique in that it is a low, stable, highly weathered plateau with granite outcrops (monadnocks or inselbergs) occasionally emergent. There are a few small mountainous areas, with a maximum elevation just over $1000 \mathrm{~m}$ (in the Stirling Range) (Fig. 1.9). The nutrient-impoverished, seasonally dry soils of the SouthWest have resulted in a flora evolving that is predominantly sclerophyllous (literally 'hardleaved') trees, shrubs and perennial herbs (Hopper, 2009). About 7\% of the flora contains monocotyledonous geophytes (Parsons \& Hopper, 2003). About 58\% of the SouthWest vascular flora currently is endemic here (Mucina et al., 2014). This value can be expected to rise to $75 \%$ based on the current rate of descriptions of taxa, almost all of which are endemic, and as phytogeographic methods move away from the grid system of determining occurrence that overestimates species distribution east of the SouthWest. Endemism and species richness is greatest by far in the upland areas, 
especially the Mt Lesueur-Eneabba region, the Stirling Range and the Barren Ranges (Hopper, 1979; Groom \& Lamont, 1996a; Lamont \& Connell, 1996; Beard et al., 2000) (Fig. 1.9). It is these areas that best define the uniqueness of the SouthWest flora.
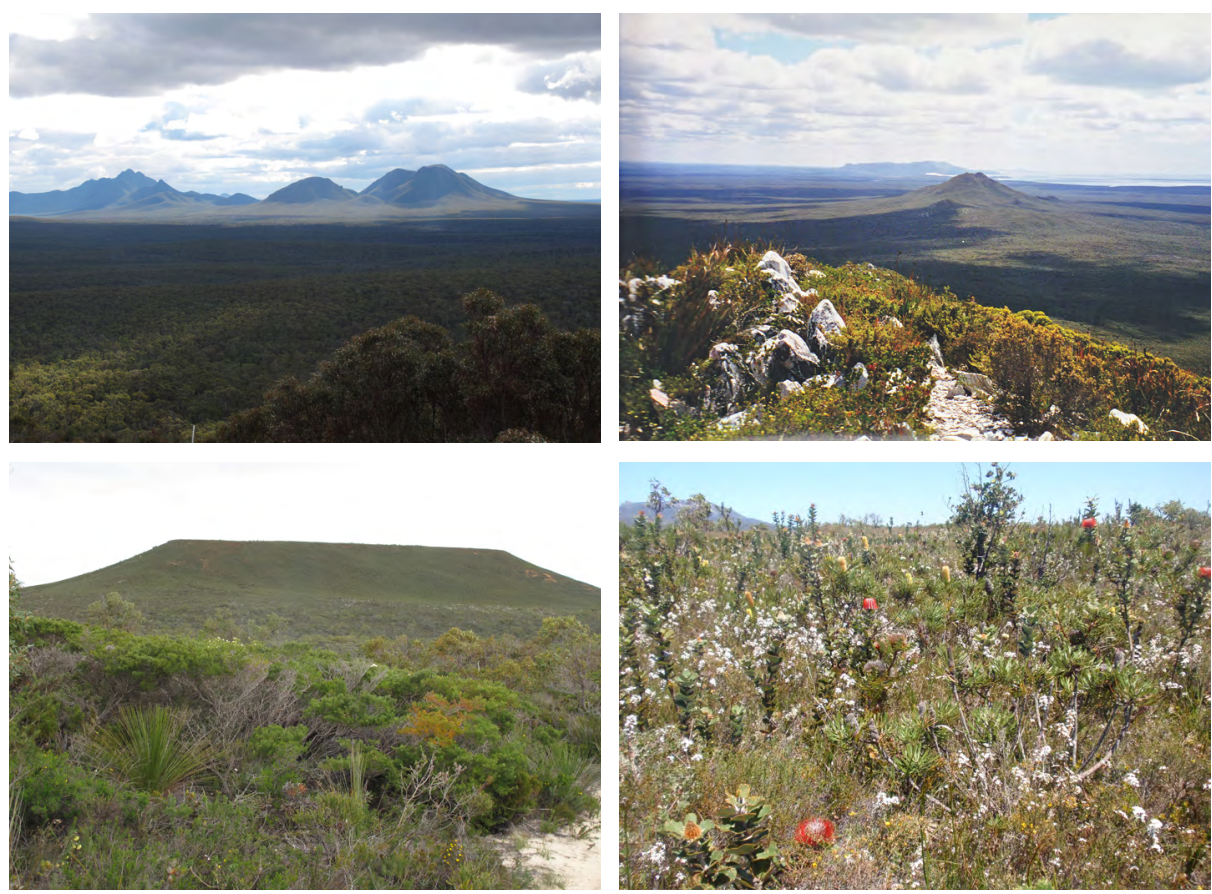

Fig. 1.9: (upper left) The Stirling Range. Bluff Knoll is the highest point in the SouthWest $(1,099 \mathrm{~m}$ above sea level (asl)). (upper right): The Barren Ranges, Fitzgerald River National Park. West Mt Barren is 377 asl. (lower left) Mt Lesueur (313 m asl), a near-circular flat-topped mesa. (lower right) species-rich shrubland surrounding Mt Manypeaks (565 m asl), $35 \mathrm{~km} \mathrm{NE}$ of Albany on the south coast of the SouthWest. Maximum height of shrubland species is $2.5 \mathrm{~m}$. Banksias in flower are $B$. coccinea (red) and $B$. attenuata (yellow) to a maximum height of $2 \mathrm{~m}$, with a white-flowered subshrub, possibly Sphenotoma sp. (Ericaceae), abundant.

Ironstone ranges and granite outcrops of the woodlands and arid shrublands exhibit high levels of local endemism, differing in species composition, diversity and microclimate from the surrounding landscapes (Gibson et al., 2010; Schut et al., 2014). Species restricted to fissures in these formations have specialised root morphologies that enable access to stored moisture sources in the underlying rock (Poot \& Lambers, 2008; Poot et al., 2012). Both granite outcrops and ironstone ranges may have acted as refugia during the transition to drier, seasonal cclimates of the Cenozoic Era (Gibson et al., 2012; Keppel et al., 2012). 
Table 1.4: The ten taxa-richest families and genera in the SouthWest with number of taxa in parentheses. Data obtained from Florabase (http://florabase.dpaw.wa.gov.au/), Western Australian Herbarium's online taxa database. Data accessed 10 October 2013. Melaleuca was expanded in 2014 to include many other related genera not added here.

\section{Families}

Myrtaceae (1268) - Eucalypt family

Fabaceae (1026) - Legume family

Proteaceae (765) - Banksia family

Orchidaceae (382) - Orchid family

Ericaceae (371) - Epacrid family

Asteraceae (290) - Daisy family

Cyperaceae (250) - Sedge family

Stylidiaceae (217) - Triggerplant family

Goodeniaceae (204) - Wing-petalled family

Malvaceae (184) - Mallow family

\section{Genera}

Acacia (438) - Fabaceae

Eucalyptus (313) - Myrtaceae

Leucopogon (209) - Ericaceae

Stylidium (208) - Stylidiaceae

Grevillea (195) - Proteaceae

Melaleuca (182) - Myrtaceae

Banksia (156) - Proteaceae

Caladenia (146) - Orchidaceae

Gastrolobium (111) - Fabaceae

Hakea (100) - Proteaceae

Baeckea (100) - Myrtaceae 